\title{
Dyscyplina finansów publicznych oraz jej naruszenia w świetle działalności Komisji Orzekającej przy Regionalnej Izbie Obrachunkowej w Bydgoszczy
}

The discipline of public finances and its breach in the light of the activity of the Regional Commission at the Regional Chamber of Audit in Bydgoszcz

Streszczenie. Dyscyplina finansów publicznych oznacza obowiązek przestrzegania prawa w zakresie gospodarki finansowej przez pracowników sektora finansów publicznych i inne osoby dysponujące środkami publicznymi. Ustawodawstwo przewiduje kilkadziesiąt rodzajów naruszeń dyscypliny finansów publicznych. Opracowanie przedstawia procedurę postępowania i działalność orzeczniczą Regionalnej Komisji Orzekającej w Sprawach o Naruszenie Dyscypliny Finansów Publicznych przy Regionalnej Izbie Obrachunkowej w Bydgoszczy oraz związane z tą działalnością zagadnienia prawne.

Słowa kluczowe: publiczna gospodarka finansowa; naruszenia prawa finansowego; działalność kontrolna i orzecznicza. 


\begin{abstract}
The discipline of public finances means the obligation to comply with legal regulations concerning the financial management in the public sector. The financial regulations determine a lot of types of breaches of law in the field of public finances. The study presents a procedure and activity of the Regional Commission at the Regional Chamber of Audit in Bydgoszcz and related to this activity legal issues.
\end{abstract}

Keywords: public finance; breach of financial law; the control activity.

\title{
1. Uwagi ogólne
}

W sektorze publicznym nie działają rynkowe mechanizmy ekonomiczne, które by wymuszały określone zachowania i efektywność gospodarowania powierzonymi środkami. Racjonalne i efektywne gospodarowanie środkami publicznymi można osiągnąć tylko poprzez konsekwentne egzekwowanie określonych norm i zasad prawnych dotyczących gromadzenia i wydatkowania środków publicznych.

Niezakłócone funkcjonowanie mechanizmów finansów publicznych możliwe jest wtedy, gdy podmioty dysponujące środkami publicznymi przestrzegają ustalonych przez prawo określonych reguł gospodarowania nimi, a więc zachowują ustaloną w tym zakresie dyscyplinę. Dyscyplina finansów publicznych oznacza obowiązek przestrzegania zasad gospodarki finansowej określonych w ustawie o finansach publicznych oraz innych aktach prawnych regulujących zasady gospodarowania środkami publicznymi.

Pojęcie dyscypliny finansów publicznych nie zostało jednak zdefiniowane $\mathrm{w}$ ustawie o finansach publicznych $^{1}$ ani $\mathrm{w}$ ustawie o odpowiedzialności za naruszenie dyscypliny finansów publicznych ${ }^{2}$. Ustawodawca dokonał jednak enumeratywnego wyliczenia czynów, które uznane zostały za naruszenie dyscypliny finansów publicznych, oraz wskazał osoby, które mogą ponosić odpowiedzialność za jej naruszenie.

1 Ustawa z dnia 27 sierpnia 2009 r. o finansach publicznych (tekst jedn. Dz.U. z 2013 r., poz. 885 ze zm.).

2 Ustawa z dnia 17 grudnia 2004 r. o odpowiedzialności za naruszenie dyscypliny finansów publicznych (Dz.U. z 2013 poz. 168), dalej: u.o.n.d.f.p. 
Naruszeniem dyscypliny finansów publicznych jest popełnienie czynów określonych w art. 5-18 c u.o.n.d.f.p. W świetle tych przepisów wyróżnić można kilkadziesiąt rodzajów naruszeń.

Odpowiedzialność za naruszenie dyscypliny finansów publicznych jest odpowiedzialnością personalną. Obowiązujące w tym zakresie przepisy odnoszą się w każdym przypadku do osób, a nie do instytucji. Naruszenie dyscypliny finansów publicznych nie musi wiązać się z powstaniem szkody w majątku Skarbu Państwa czy jednostki samorządu terytorialnego lub innego podmiotu publicznego. Jest już nim samo naruszenie reguł funkcjonowania sektora publicznego, nawet jeśli nie spowodowało realnych negatywnych skutków, choć mogło do takich prowadzić.

Niniejsze opracowanie przedstawia procedurę postępowania i działalność orzeczniczą Regionalnej Komisji Orzekającej w Sprawach o Naruszenie Dyscypliny Finansów Publicznych przy Regionalnej Izbie Obrachunkowej w Bydgoszczy oraz związane z tą działalnością problemy prawne.

\section{Zasady odpowiedzialności}

Odpowiedzialność za naruszenie dyscypliny finansów publicznych to odpowiedzialność osób winnych popełnienia czynów uznanych przez ustawę o odpowiedzialności za naruszenie dyscypliny finansów publicznych za wspomniane naruszenia. Podmiotowy zakres odpowiedzialności ujęty przez ustawę jest dość szeroki i obejmuje pracowników sektora finansów publicznych, a także inne osoby, w tym również osoby dysponujące środkami publicznymi przekazanymi podmiotom spoza sektora finansów publicznych.

Odpowiedzialności tej podlegają (art. 4 u.o.n.d.f.p.):

a. osoby wchodzące w skład organu wykonującego budżet (organu wykonawczego), tj. osoby wchodzące w skład zarządu województwa samorządowego, zarządu powiatu oraz wójt (burmistrz, prezydent) jako jednoosobowe organy wykonawcze wykonujące budżet, a także członkowie zarządów związków komunalnych gmin i powiatów, 
b. osoby wchodzące w skład organu zarządzającego podmiotu niezaliczanego do sektora finansów publicznych, któremu przekazano do wykorzystania lub dysponowania środki publiczne, lub zarządzającego mieniem tych jednostek lub podmiotów,

c. kierownicy jednostek sektora finansów publicznych, tj. wójt (burmistrz, prezydent), starosta, marszałek województwa jako kierownicy, będącej jednostką budżetową, jednostki pomocniczej (urzędu) gminy, powiatu oraz województwa samorządowego,

d. kierownicy jednostek organizacyjnych jednostek samorządu terytorialnego,

e. kierownicy komunalnych osób prawnych (instytucji kultury, samodzielnych publicznych zakładów opieki zdrowotnej),

f. pracownicy jednostek sektora finansów publicznych lub inne osoby, którym odrębną ustawą lub na jej podstawie powierzono wykonywanie obowiązków w takiej jednostce, których niewykonanie lub nienależyte wykonanie stanowi czyn naruszający dyscyplinę finansów publicznych, np. skarbnicy, główni księgowi, osoby, którym powierzono zadania $\mathrm{z}$ zakresu realizacji zamówień publicznych,

g. osoby wykonujące w imieniu podmiotu niezaliczanego do sektora finansów publicznych, któremu przekazano do wykorzystania lub dysponowania środki publiczne, czynności związane z wykorzystaniem tych środków lub dysponowaniem tymi środkami.

Odpowiedzialności, o której mowa, podlegają również osoby zobowiązane lub upoważnione do działania w imieniu podmiotu, któremu powierzono określone zadania związane $\mathrm{z}$ realizacją programu finansowanego z udziałem środków pochodzących z budżetu Unii Europejskiej lub innych środków pochodzących ze źródeł zagranicznych niepodlegających zwrotowi.

Osoby, o których mowa wyżej, ponoszą odpowiedzialność zarówno za umyślne, jak i za nieumyślne naruszenie dyscypliny finansów publicznych, przy czym może ono mieć formę i określonego działania i zaniechania. Odpowiedzialność, o której mowa, wyłączona jest tylko wtedy, gdy naruszenia nie można było uniknąć nawet przy dołożeniu najwyższej 
staranności, wymaganej od osób odpowiedzialnych za dobro finansów publicznych. Określenie „najwyższej staranności” nie zostało jednak bliżej sprecyzowane czy zdefiniowane. Tym samym przepis wyłączający z tego powodu odpowiedzialność pozwala na znaczną dowolność interpretacyjną.

Okolicznością wyłączającą odpowiedzialność może być w pewnych okolicznościach działanie na polecenie przełożonego. Może to mieć miejsce w takim przypadku, gdy pracownik, który otrzymał polecenie działania naruszającego dyscyplinę finansów publicznych, przed jego wykonaniem zgłosił na piśmie swojemu przełożonemu odpowiednie zastrzeżenie i pomimo to otrzymał pisemne potwierdzenie wykonania polecenia. W takiej sytuacji odpowiedzialność ponosi kierownik jednostki lub inny przełożony pracownika, który wydał takie polecenie. Pisemne polecenie przełożonego nie zwalnia jednak pracownika od odpowiedzialności, kiedy wykonanie tego polecenia stanowić będzie przestępstwo lub wykroczenie (art. 29 u.o.n.d.f.p.).

W sprawach o naruszenie dyscypliny finansów publicznych stosuje się również wyłączenie odpowiedzialności osób działających w stanie wyłączonej poczytalności, o ile nie zostało ono spowodowane w wyniku własnego działania sprawcy.

Odpowiedzialność za naruszenie dyscypliny finansów publicznych jest niezależna od innej odpowiedzialności określonej przepisami prawa. W razie jednak wszczęcia postępowania karnego ${ }^{3}$, karnego skarbowego ${ }^{4}$ w związku z przestępstwem naruszającym równocześnie dyscyplinę finansów publicznych, postępowanie o naruszenie dyscypliny finansów publicznych zawiesza się do czasu zakończenia wspomnianych postępowań.

W przypadku wyroku skazującego za przestępstwo stanowiące równocześnie naruszenie dyscypliny finansów publicznych, wszczęte postępowanie o naruszenie dyscypliny finansów publicznych umarza się. Jeżeli zaś zostało ono przed wszczęciem postępowania karnego lub karnego

\footnotetext{
Ustawa z dnia 6 czerwca 1997 r. Kodeks karny (Dz.U. Nr 88, poz. 553 ze zm.).

4 Ustawa z dnia 10 września 1999 r. Kodeks karny skarbowy (Dz.U. z 2013 r., poz. 186 ze zm.).
} 
skarbowego zakończone, to co prawda nie powoduje to wzruszenia wydanego orzeczenia, ale jeżeli nadal nie wyegzekwowano na przykład orzeczonych kar pieniężnych, to nie podlegają one już ściągnięciu.

\section{Postępowanie w sprawach o naruszenie dyscypliny finansów publicznych}

\subsection{Podmioty postępowania}

Podmiotami postępowania w sprawach o naruszenie dyscypliny finansów publicznych są strony tego procesu oraz organ je prowadzący. Stronami postępowania są obwiniony i rzecznik dyscypliny finansów publicznych pełniący funkcję oskarżyciela. Obwinionym jest osoba, co do której rzecznik dyscypliny finansów publicznych złożył wniosek o ukaranie za naruszenie dyscypliny finansów publicznych. Obwiniony w trakcie postępowania może korzystać z pomocy obrońcy.

Głównego rzecznika dyscypliny finansów publicznych powołuje i odwołuje Prezes Rady Ministrów na wniosek Ministra Finansów. Natomiast zastępców głównego rzecznika powołuje Prezes Rady Ministrów na wniosek głównego rzecznika. Rzecznika właściwego w sprawach rozpatrywanych przez wspólną komisję orzekającą i jego zastępców powołuje i odwołuje Prezydent Rzeczpospolitej Polskiej. Rzeczników zaś właściwych w sprawach rozpatrywanych w pierwszej instancji m.in. przez regionalne komisje orzekające i ich zastępców powołuje i odwołuje główny rzecznik dyscypliny finansów publicznych spośród kandydatów rekomendowanych przez prezesów regionalnych izb obrachunkowych oraz wojewodów (art. 60 ust. 1 u.o.n.d.f.p.).

Postępowanie w sprawach o naruszenie dyscypliny finansów publicznych jest dwuinstancyjne. Funkcję organów I instancji pełni kilka rodzajów komisji orzekających, różniących się właściwością. W tym zakresie funkcjonują:

1. wspólna komisja orzekająca właściwa w sprawach o naruszenie dyscypliny finansów publicznych $\mathrm{w}$ zakresie realizacji budżetu 
państwa w częściach dotyczących najwyższych organów władzy państwowej (np. Kancelarii Sejmu, Kancelarii Senatu, Kancelarii Prezydenta RP, Sądu Najwyższego, Trybunału Konstytucyjnego, Najwyższej Izby Kontroli),

2. międzyresortowa komisja orzekająca - przy ministrze właściwym do spraw finansów publicznych,

3. międzyresortowa komisja orzekająca - przy ministrze właściwym do spraw administracji publicznej,

4. międzyresortowa komisja orzekająca - przy Ministrze Sprawiedliwości,

5. komisja orzekająca - przy Szefie Kancelarii Prezesa Rady Ministrów,

6. regionalne komisje orzekające - przy regionalnych izbach obrachunkowych, zgodnie $\mathrm{z}$ terytorialnym zasięgiem działania regionalnej izby obrachunkowej, właściwe w sprawach o naruszenie dyscypliny finansów publicznych w zakresie dotyczącym:

a. jednostek samorządu terytorialnego, ich związków i stowarzyszeń z wyłączeniem osób pełniących funkcję marszałka województwa, członka zarządu województwa i skarbnika województwa,

b. realizacji budżetu wojewody, z wyłączeniem osób pełniących funkcję wojewody, wicewojewody, dyrektora generalnego urzędu wojewódzkiego i głównego księgowego części budżetowej, której dysponentem jest wojewoda,

c. jednostek podległych i nadzorowanych przez wojewodę,

d. samorządowych jednostek organizacyjnych, w tym samorządowych osób prawnych,

e. innych jednostek otrzymujących środki publiczne pochodzące z budżetów jednostek samorządu terytorialnego lub innych środków publicznych, którymi dysponują te jednostki,

f. innych jednostek w zakresie środków otrzymanych z budżetu wojewody lub innych środków, którymi dysponuje wojewoda.

Organem Orzekającym w sprawach o naruszenie dyscypliny finansów publicznych w drugiej instancji jest Główna Komisja Orzekająca przy Ministrze Finansów. Kadencje wszystkich rodzajów komisji trwają cztery lata. Członkowie komisji orzekających w zakresie orzekania są niezawiśli i podlegają tylko ustawom. 
W dalszej części opracowania jego przedmiotem będzie tylko funkcjonowanie regionalnych komisji orzekających przy regionalnych izbach obrachunkowych.

\subsection{Tryb postępowania}

Kierownicy jednostek sektora finansów publicznych lub jednostek korzystających ze środków publicznych oraz organy kontroli, a także organ stanowiący jednostki samorządu terytorialnego, organ sprawujący nadzór nad jednostką sektora finansów publicznych, komisja stała organu stanowiącego samorządu terytorialnego, organ założycielski jednostki sektora finansów publicznych, dysponent przekazujący środki publiczne jednostce sektora finansów publicznych lub podmiotowi niezaliczanemu do sektora finansów publicznych $\mathrm{w}$ razie ujawnienia naruszenia dyscypliny finansów publicznych niezwłocznie powiadamiają o tym fakcie właściwego rzecznika dyscypliny finansów publicznych. Rzecznik na podstawie zawiadomienia ustala, czy istnieją przesłanki do wszczęcia postępowania wyjaśniającego. Po zakończeniu tych czynności wydaje postanowienie o wszczęciu postępowania wyjaśniającego bądź o odmowie jego wszczęcia. W terminie nie dłuższym niż 120 dni od dnia otrzymania zawiadomienia rzecznik występuje $\mathrm{z}$ wnioskiem o ukaranie albo wydaje postanowienie o umorzeniu postępowania wyjaśniającego. Wniosek o ukaranie rzecznik dyscypliny przekazuje przewodniczącemu właściwej komisji orzekającej (por. art. 93 ust. 1, art. 96 ust. 1, art. 104 ust. 1 u.o.n.d.f.p.).

Przewodniczący komisji orzekającej dokonuje wstępnej oceny jego poprawności. O ile nie spełnia on wymogów określonych w ustawie o odpowiedzialności za naruszenie dyscypliny finansów publicznych, przewodniczący komisji orzekającej w terminie 14 dni od jego otrzymania zarządza zwrot wniosku do uzupełnienia organowi, który z nim wystąpił. O ile wniosek o ukaranie jest poprawny, przewodniczący komisji orzekającej w terminie 14 dni od dnia jego otrzymania zarządza doręczenie odpisu wniosku obwinionemu i kieruje wniosek do rozpoznania na posiedzeniu lub rozprawie. wyznaczając ich terminy oraz 
trzyosobowy skład orzekający i wskazując przewodniczącego tego składu (por. art. 112, art. 113 u.o.n.d.f.p.).

O terminie i miejscu rozprawy przewodniczący komisji powiadamia strony postępowania i obrońcę obwinionego, o ile został on ustanowiony. Obecność na rozprawie obwinionego lub jego obrońcy nie jest obowiązkowa.

Rozprawa przed komisją orzekającą jest jawna. Wyłączenie jawności rozprawy lub jej części może nastąpić wyłącznie ze względu na bezpieczeństwo państwa lub ochronę informacji niejawnych, bądź ze względu na zagrożenie spokoju i porządku publicznego ${ }^{5}$.

Komisja orzekająca orzeka na podstawie materiału dowodowego ujawnionego na rozprawie i rozstrzyga większością głosów, wydając albo orzeczenie o odpowiedzialności za naruszenie dyscypliny finansów publicznych uznające winę obwinionego, albo orzeczenie o uniewinnieniu, albo orzeczenie o umorzeniu postępowania.

\subsection{Orzeczenia w zakresie kar}

Wydając orzeczenie o winie, komisja orzeka również o karze. W postępowaniu o naruszenie dyscypliny finansów publicznych karami są (art. 31 u.o.n.d.f.p.):

- upomnienie,

- nagana,

- kara pieniężna,

- zakaz pełnienia funkcji związanych z dysponowaniem środkami publicznymi.

Kara upomnienia jest karą najłagodniejszą i wymierza się ją w przypadku, gdy stopień szkodliwości naruszenia dyscypliny finansów publicznych nie jest znaczny. Kara ta jest związana z ujemną oceną kwalifikacyjną ukaranego. Skutki wynikające z ujemnej lub negatywnej oceny kwalifikacyjnej ukaranego dotyczą również ukarania karą nagany lub karą pieniężną.

\footnotetext{
$5 \quad$ Art. 119 u.o.n.d.f.p.
} 
Karę pieniężną wymierza się w wysokości od 0,25 do trzykrotności miesięcznego wynagrodzenia osoby odpowiedzialnej za naruszenie dyscypliny finansów publicznych - obliczonego jak wynagrodzenie za czas urlopu wypoczynkowego - należnego w roku, w którym doszło do tego naruszenia. Jeżeli natomiast nie jest możliwe ustalenie wysokości wynagrodzenia w sposób określony wyżej, karę pieniężną wymierza się w wysokości od 0,25 do pięciokrotności przeciętnego wynagrodzenia ${ }^{6}$.

Karę zakazu pełnienia funkcji związanych $\mathrm{z}$ dysponowaniem środkami publicznymi wymierza się w przypadku rażącego naruszenia dyscypliny finansów publicznych. Karę tę można wymierzyć również w przypadku ponownego ukarania za naruszenie dyscypliny finansów publicznych $^{7}$.

Ukaranie karą zakazu pełnienia funkcji związanych z dysponowaniem środkami publicznymi wyklucza, przez czas określony w orzeczeniu o ukaraniu, możliwość (art. 32 ust. 2 u.o.n.d.f.p.):

1. pełnienia funkcji w jednostkach sektora finansów publicznych:

a. kierownika, zastępcy kierownika lub dyrektora generalnego,

b. członka zarządu,

c. skarbnika, głównego księgowego lub zastępcy głównego księgowego,

d. kierownika lub zastępcy kierownika komórki bezpośrednio odpowiedzialnej za wykonanie budżetu lub planu finansowego.

2. reprezentowania interesów majątkowych Skarbu Państwa, jednostek samorządu terytorialnego lub innej jednostki sektora finansów publicznych,

3. członkostwa w organach stanowiących, nadzorujących i wykonawczych państwowych i samorządowych osób prawnych.

Kara, o której wyżej mowa, nie ogranicza prawa wybieralności (biernego prawa wyborczego) na wójta, burmistrza i prezydenta miasta ${ }^{8}$.

Karę zakazu pełnienia funkcji związanych $\mathrm{z}$ dysponowaniem środkami publicznymi wymierza się na okres od roku do 5 lat ${ }^{9}$.

\footnotetext{
Art. 31 u.o.n.d.f.p.

Art. 34 u.o.n.d.f.p.

Art. 32 ust. 3 u.o.n.d.f.p.
} 
Postępowanie w zakresie wykonywania orzeczonej kary zakazu pełnienia funkcji związanych $\mathrm{z}$ dysponowaniem środkami publicznymi jest uzależnione od tego, czy ukarany pełni taką funkcję, czy też jej nie sprawuje. Jeżeli ukarany pełni taką funkcję, wykonanie kary polega na odwołaniu ukaranego z funkcji objętej zakazem, natomiast gdy takiej funkcji nie sprawuje, wykonanie kary sprowadza się do niepowoływania ukaranego na funkcje objęte zakazem w okresie, na jaki kara została orzeczona.

W wypadku orzeczenia tego rodzaju kary wobec wójta, burmistrza lub prezydenta miasta przewodniczący komisji orzekającej przekazuje orzeczenie właściwemu wojewodzie i dołącza wezwanie do wystąpienia z wnioskiem o odwołanie w trybie określonym w art. 96 ust. 2 ustawy z dnia 8 marca 1990 r. o samorządzie gminnym ${ }^{10}$ (art. 156 ust. 2 u.o.n.d.f.p.).

W wyjątkowych i uzasadnionych, zasługujących na szczególne uwzględnienie przypadkach komisja, biorąc pod uwagę rodzaj i okoliczności naruszenia dyscypliny finansów publicznych lub właściwości i warunki osobiste sprawcy naruszenia dyscypliny finansów publicznych, może wydać orzeczenie o winie obwinionego i odstąpić od wymierzenia kary.

Jako okoliczności łagodzące można uwzględnić w szczególności:

1. działanie lub zaniechanie ze szczególnych pobudek lub w szczególnych warunkach, zasługujących na uwzględnienie, w tym w celu zapobieżenia szkodzie w mieniu publicznym,

2. wyróżnianie się przed popełnieniem naruszenia dyscypliny finansów publicznych wzorowym spełnianiem obowiązków zawodowych,

3. przyczynienie się do usunięcia szkodliwych następstw naruszenia dyscypliny finansów publicznych lub podjęcie o to starań ${ }^{11}$.

Od orzeczenia komisji orzekającej I instancji stronom przysługuje odwołanie. Odwołanie wnosi się do Głównej Komisji Orzekającej na piśmie za pośrednictwem organu, który wydał zaskarżone orzeczenie, w terminie 14 dni od dnia jego doręczenia. Orzeczenia Głównej Komisji Orzekającej kończące postępowanie są prawomocne w dniu ich wydania. Przysługuje jednak na nie skarga do właściwego sądu administracyjnego.

\footnotetext{
$9 \quad$ Art. 31 ust. 4 u.o.n.d.f.p.

10 Tekst jedn. Dz.U. z 2013 r., poz. 594 ze zm.

11 Art. 36 ust. 1 i 2 u.o.n.d.f.p.
} 


\section{Naruszenie dyscypliny finansów publicznych będące przedmiotem orzekania przez Regionalną Komisję Orzekającą przy Regionalnej Izbie Obrachunkowej w Bydgoszczy.}

W latach 2013-2014 do Komisji Orzekającej przy Regionalnej Izbie Obrachunkowej w Bydgoszczy wpłynęło łącznie 89 wniosków o ukaranie w stosunku do 109 obwinionych. W poszczególnych latach przedstawiało się to następująco:

Tabela 1. Wnioski o ukaranie, jakie w latach 2013-2014 wpłynęły do Regionalnej Komisji Orzekającej przy Regionalnej Izbie Obrachunkowej w Bydgoszczy.

\begin{tabular}{|l|l|c|c|}
\hline Lp. & \multicolumn{1}{|c|}{ Rok } & $\begin{array}{c}\text { Liczba wniosków } \\
\text { o ukaranie }\end{array}$ & $\begin{array}{c}\text { Liczba obwinionych według } \\
\text { złożonych wniosków o ukaranie }\end{array}$ \\
\hline 1. & 2013 & 48 & 60 \\
\hline 2. & 2014 & 41 & 43 \\
\hline & Razem & $\mathbf{8 9}$ & $\mathbf{1 0 3}$ \\
\hline
\end{tabular}

Z powyższego zestawienia wynika, że liczba wniosków o ukaranie w poszczególnych latach utrzymuje się na podobnym poziomie. Z dokumentacji prowadzonej przez Komisję wynika też, że sytuacja w tym zakresie przedstawiała się podobnie w latach poprzednich.

Wnioski o ukaranie wpływające do Komisji Orzekającej sporządzone zostały w oparciu o zawiadomienia o naruszeniu dyscypliny finansów publicznych przekazane przez zobowiązane i upoważnione do tego podmioty. Wnioski, które w omawianym okresie wpłynęły do Komisji Orzekającej, sporządzone zostały w oparciu o zawiadomienia złożone przez następujące podmioty:

Tabela 2. Zawiadomienia o naruszeniu dyscypliny finansów publicznych według podmiotów je składających.

\begin{tabular}{|c|c|c|c|c|}
\hline \multirow{3}{*}{ Lp. } & \multirow{3}{*}{ Podmiot składający zawiadomienie } & \multicolumn{3}{|c|}{ liczba zawiadomień } \\
\hline & & \multicolumn{2}{|c|}{ lata } & \multirow{2}{*}{ Razem } \\
\hline & & 2013 & 2014 & \\
\hline 1. & Prezes Regionalnej Izby Obrachunkowej & 13 & 7 & 20 \\
\hline 2. & Kierownik jednostki organizacyjnej JST & 0 & 2 & 2 \\
\hline
\end{tabular}




\begin{tabular}{|l|l|c|c|c|}
\hline 3. & Wójt & 2 & 1 & 3 \\
\hline 4. & Burmistrz & 0 & 2 & 2 \\
\hline 5. & Prezydent Miasta & 1 & 1 & 2 \\
\hline 6. & Starosta & 6 & 6 & 12 \\
\hline 7. & Wojewoda & 13 & 7 & 20 \\
\hline 8. & Marszałek Województwa & 3 & 4 & 7 \\
\hline 9. & Urząd Kontroli Skarbowej & 3 & 3 & 6 \\
\hline 10. & Najwyższa Izba Kontroli & 3 & 6 & 9 \\
\hline 11. & Urząd Zamówień Publicznych & 4 & 0 & 4 \\
\cline { 2 - 5 } & Ogółem & $\mathbf{4 8}$ & $\mathbf{3 9}$ & $\mathbf{8 7}$ \\
\cline { 2 - 5 }
\end{tabular}

W wielu zawiadomieniach o naruszeniu dyscypliny finansów publicznych, co znajdowało następnie odbicie we wnioskach o ukaranie, obwinionym stawiane były zarzuty dotyczące jednocześnie kilku naruszeń. W omawianym okresie Komisja rozstrzygała sprawy dotyczące łącznie 124 zarzutów w odniesieniu do 20 rodzajów naruszenia dyscypliny finansów publicznych. W szczegółach przedstawiało się to następująco:

Tabela 3. Naruszenia dyscypliny finansów publicznych, będące przedmiotem orzekania Komisji Orzekającej w latach 2013-2014, według poszczególnych artykułów ustawy o odpowiedzialności za naruszenie dyscypliny finansów publicznych.

\begin{tabular}{|l|l|c|c|c|}
\hline \multirow{2}{*}{ Lp. } & \multicolumn{1}{|c|}{ Rodzaj naruszenia } & \multirow{2}{*}{ Lata } & \multirow{2}{*}{ Razem } \\
\cline { 3 - 4 } 1. & $\begin{array}{l}\text { art. 5 ust. 1 pkt 1 - nieustalenie należności Skarbu } \\
\text { Państwa, jednostki samorządu terytorialnego lub } \\
\text { innej jednostki sektora finansów publicznych albo } \\
\text { ustalenie takiej należności w wysokości niższej niż } \\
\text { wynikająca z prawidłowego obliczenia. }\end{array}$ & 1 & 0 & 1 \\
\hline & $\begin{array}{l}\text { art. 5 ust. 1 pkt 2 - niepobranie lub niedocho- } \\
\text { dzenie należności Skarbu Państwa, jednostki } \\
\text { samorządu terytorialnego lub innej jednostki } \\
\text { sektora finansów publicznych albo pobranie lub } \\
\text { dochodzenie tej należności w wysokości niższej niż } \\
\text { wynikająca z prawidłowego obliczenia. }\end{array}$ & 7 & 6 & \multirow{2}{*}{13} \\
\hline
\end{tabular}




\begin{tabular}{|c|c|c|c|c|}
\hline 3. & $\begin{array}{l}\text { art. } 6 \text { - nieprzekazanie w terminie do budżetu } \\
\text { w należnej wysokości pobranych dochodów } \\
\text { należnych Skarbowi Państwa lub jednostce } \\
\text { samorządu terytorialnego; niedokonanie w terminie } \\
\text { wpłaty do budżetu w należnej wysokości } \\
\text { dochodów przez jednostkę budżetową, nadwyżki } \\
\text { środków obrotowych przez samorządowy zakład } \\
\text { budżetowy albo nadwyżki środków finansowych } \\
\text { przez agencję wykonawczą. }\end{array}$ & 9 & 1 & 10 \\
\hline 4. & $\begin{array}{l}\text { art. } 8 \text { pkt } 1 \text { - przekazanie lub udzielenie dotacji } \\
\text { z naruszeniem zasad lub trybu przekazywania lub } \\
\text { udzielania dotacji. }\end{array}$ & 5 & 5 & 10 \\
\hline 5. & $\begin{array}{l}\text { art. } 9 \text { pkt } 1 \text { - wydatkowanie dotacji niezgodnie } \\
\text { z przeznaczeniem określonym przez udzielającego } \\
\text { dotację. }\end{array}$ & 1 & 1 & 2 \\
\hline 6. & $\begin{array}{l}\text { art. } 9 \text { pkt } 3 \text { - niedokonanie w terminie zwrotu } \\
\text { dotacji w należnej wysokości. }\end{array}$ & 1 & 2 & 3 \\
\hline 7. & $\begin{array}{l}\text { art. } 11 \text { - dokonanie wydatku ze środków publicz- } \\
\text { nych bez upoważnienia określonego ustawą } \\
\text { budżetową, uchwałą budżetową lub planem } \\
\text { finansowym albo z przekroczeniem zakresu tego } \\
\text { upoważnienia lub z naruszeniem przepisów } \\
\text { dotyczących dokonywania poszczególnych } \\
\text { rodzajów wydatków. }\end{array}$ & 7 & 2 & 9 \\
\hline 8. & $\begin{array}{l}\text { art. } 13 \text { pkt } \mathbf{6}-\text { wykorzystanie środków } \\
\text { publicznych lub środków przekazanych ze środków } \\
\text { publicznych, związanych z realizacją programów } \\
\text { lub projektów finansowanych z udziałem środków } \\
\text { unijnych lub zagranicznych, niezgodnie z przezna- } \\
\text { czeniem lub z naruszeniem procedur obowią- } \\
\text { zujących przy ich wykorzystaniu. }\end{array}$ & 1 & 0 & 1 \\
\hline 9. & $\begin{array}{l}\text { art. } 14 \text { - nieopłacenie w terminie przez jednostkę } \\
\text { sektora finansów publicznych składek na } \\
\text { ubezpieczenia społeczne, składek na ubezpieczenie } \\
\text { zdrowotne, składek na Fundusz Pracy, składek na } \\
\text { Fundusz Gwarantowanych Świadczeń } \\
\text { Pracowniczych, wpłat na Państwowy Fundusz } \\
\text { Rehabilitacji Osób Niepełnosprawnych albo ich } \\
\text { opłacenie w kwocie niższej niż wynikająca } \\
\text { z prawidłowego obliczenia. }\end{array}$ & 5 & 0 & 5 \\
\hline
\end{tabular}




\begin{tabular}{|c|c|c|c|c|}
\hline 10. & $\begin{array}{l}\text { art. } 15 \text { - zaciagnnięcie zobowiązania bez upoważ- } \\
\text { nienia określonego ustawą budżetową, uchwałą } \\
\text { budżetową lub planem finansowym albo } \\
\text { z przekroczeniem zakresu tego upoważnienia lub } \\
\text { z naruszeniem przepisów dotyczących zaciągania } \\
\text { zobowiązań przez jednostkę sektora finansów } \\
\text { publicznych. }\end{array}$ & 2 & 1 & 3 \\
\hline 11. & $\begin{array}{l}\text { art. } 16 \text { - niewykonanie w terminie zobowiązania } \\
\text { jednostki sektora finansów publicznych, w tym } \\
\text { obowiązku zwrotu należności celnej, podatku, } \\
\text { nadpłaty lub nienależnie opłaconych składek na } \\
\text { ubezpieczenie społeczne lub zdrowotne, którego } \\
\text { skutkiem jest zapłata odsetek, kar lub opłat albo } \\
\text { oprocentowanie tych należności. }\end{array}$ & 5 & 7 & 12 \\
\hline 12. & $\begin{array}{l}\text { art. } 17 \text { ust. } 1 \text { - niezgodne z przepisami o zamó- } \\
\text { wieniach publicznych opisanie przedmiotu } \\
\text { zamówienia publicznego, ustalenie wartości } \\
\text { zamówienia publicznego, opisanie sposobu } \\
\text { dokonania oceny spełniania warunków udziału } \\
\text { w postępowaniu, określenie kryteriów oceny ofert, } \\
\text { nieprzekazanie do ogłoszenia w Dzienniku } \\
\text { Urzędowym Unii Europejskiej lub niezamie- } \\
\text { szczenie w Biuletynie Zamówień Publicznych } \\
\text { ogłoszenia o zamówieniu, ogłoszenia o zmianie lub } \\
\text { ogłoszenia o udzieleniu zamówienia, niezawia- } \\
\text { domienie w terminie Prezesa Urzędu Zamówień } \\
\text { Publicznych o wszczęciu postępowania o udzie- } \\
\text { lenie zamówienia. }\end{array}$ & 1 & 1 & 2 \\
\hline 13. & $\begin{array}{l}\text { art. } 17 \text { ust. 1b - udzielenie zamówienia publicz- } \\
\text { nego wykonawcy, który nie został wybrany } \\
\text { w trybie określonym w przepisach o zamówieniach } \\
\text { publicznych, bądź z naruszeniem przepisów } \\
\text { o zamówieniach publicznych dotyczących przesła- } \\
\text { nek stosowania trybów udzielenia zamówienia } \\
\text { publicznego: negocjacji bez ogłoszenia, zamó- } \\
\text { wienia z wolnej ręki lub zapytania o cenę. }\end{array}$ & 18 & 10 & 28 \\
\hline 14. & $\begin{array}{l}\text { art. } 17 \text { ust. 1c - naruszenie przepisów o zamówie- } \\
\text { niach publicznych w inny sposób niż określony } \\
\text { w ust. } 1 \text { i } 1 \text { b, jeżeli miało ono wpływ na wynik } \\
\text { postępowania o udzielenie zamówienia publicz- } \\
\text { nego, chyba że nie doszło do udzielenia zamó- } \\
\text { wienia publicznego. }\end{array}$ & 1 & 0 & 1 \\
\hline
\end{tabular}




\begin{tabular}{|c|c|c|c|c|}
\hline 15. & $\begin{array}{l}\text { art. } 17 \text { ust. } 2 \text { - zawarcie umowy w sprawie zamó- } \\
\text { wienia publicznego bez zachowania formy } \\
\text { pisemnej; na czas dłuższy niż określony } \\
\text { w przepisach o zamówieniach publicznych lub na } \\
\text { czas nieoznaczony, z wyłączeniem przypadków } \\
\text { dopuszczonych w przepisach o zamówieniach } \\
\text { publicznych; przed ogłoszeniem orzeczenia przez } \\
\text { Krajowá Izbę Odwoławczą, z naruszeniem } \\
\text { przepisów o zamówieniach publicznych. }\end{array}$ & 2 & 1 & 3 \\
\hline 16. & $\begin{array}{l}\text { art. } 17 \text { ust. } 4 \text { - niezłożenie przez członka komisji } \\
\text { przetargowej lub inną osobę wykonującą czynności } \\
\text { w postępowaniu o udzielenie zamówienia } \\
\text { publicznego po stronie zamawiającego oświad- } \\
\text { czenia o braku lub istnieniu okoliczności powo- } \\
\text { dujących wyłączenie z tego postępowania. }\end{array}$ & 1 & 1 & 2 \\
\hline 17. & $\begin{array}{l}\text { art. } 17 \text { ust. } 5 \text { - niewyłączenie } \mathrm{z} \text { postępowania } \\
\text { o udzielenie zamówienia publicznego osoby } \\
\text { podlegającej wyłączeniu z takiego postępowania na } \\
\text { podstawie przepisów o zamówieniach publicznych. }\end{array}$ & 0 & 1 & 1 \\
\hline 18. & $\begin{array}{l}\text { art. } 17 \text { ust. } 6 \text { - zmiana umowy w sprawie } \\
\text { zamówienia publicznego z naruszeniem przepisów } \\
\text { o zamówieniach publicznych. }\end{array}$ & 1 & 1 & 2 \\
\hline 19. & $\begin{array}{l}\text { art. } \mathbf{1 8} \text { pkt } \mathbf{1} \text { - zaniechanie przeprowadzenia lub } \\
\text { rozliczenia inwentaryzacji albo przeprowadzenie } \\
\text { lub rozliczenie inwentaryzacji w sposób niezgodny } \\
\text { z przepisami ustawy z dnia } 29 \text { września } 1994 \text { r. } \\
\text { o rachunkowości. }\end{array}$ & 1 & 5 & 6 \\
\hline 20. & $\begin{array}{l}\text { art. } 18 \text { pkt } 2 \text { - niesporządzenie lub nieprzekazanie } \\
\text { w terminie sprawozdania z wykonania procesów } \\
\text { gromadzenia środków publicznych i ich rozdys- } \\
\text { ponowania albo wykazanie w tym sprawozdaniu } \\
\text { danych niezgodnych z danymi wynikającymi } \\
\text { z ewidencji księgowej. }\end{array}$ & 4 & 6 & 10 \\
\hline & Ogółem & 73 & 51 & 124 \\
\hline
\end{tabular}

Po rozpoznaniu wniesionych spraw w latach 2013-2014 Komisja Orzekająca wydała łącznie 110 orzeczeń. Z tej liczby 30 orzeczeń dotyczyło uznania obwinionych winnymi naruszenia dyscypliny finansów publicznych, przy czym w 20 przypadkach odstąpiono od wymierzenia kary, a pozostałe to umorzenia postępowania i orzeczenia o uniewinnieniu 
obwinionych. Szczegółowo liczbę wydanych orzeczeń i rodzaje orzeczonych kar przedstawia poniższe zestawienie.

Tabela 4. Ilość i rodzaj orzeczeń wydanych w latach 2013-2014.

\begin{tabular}{|l|l|c|c|c|}
\hline \multirow{2}{*}{ Lp. } & \multicolumn{2}{|c|}{ Rodzaje orzeczonych kar } & \multicolumn{3}{|c|}{ Liczba orzeczeń } \\
\cline { 3 - 5 } & & 2013 & 2014 & Razem \\
\hline 1. & Umorzenie & 23 & 7 & 30 \\
\hline 2. & Uniewinnienie & 28 & 22 & 50 \\
\hline 3. & Uznanie winnym i odstąpienie od wymierzenia kary & 11 & 9 & 20 \\
\hline 4. & Upomnienie & 7 & 2 & 9 \\
\hline 5. & Nagana & 0 & 1 & 1 \\
\hline 6. & Kara pieniężna & 0 & 0 & 0 \\
\hline 7. & $\begin{array}{l}\text { Zakaz pełnienia funkcji związanych z dysponowa- } \\
\text { niem środkami publicznymi }\end{array}$ & 0 & 0 & 0 \\
\hline & Ogółem & $\mathbf{6 9}$ & $\mathbf{4 1}$ & $\mathbf{1 1 0}$ \\
\cline { 2 - 5 }
\end{tabular}

\section{Uwagi końcowe}

Aktualnie funkcjonujące regionalne komisje orzekające, w liczbie szesnastu w kraju, są samodzielnymi podmiotami funkcjonującymi w oparciu o przepisy ustawy o odpowiedzialności za naruszenie dyscypliny finansów publicznych. Nie są one organami regionalnych izb obrachunkowych ani ich jednostkami organizacyjnymi. Prezesi regionalnych izb obrachunkowych zapewniają siedzibę, obsługę prawną i administracyjno-techniczną komisji orzekających oraz rzecznika i jego zastępców właściwych w sprawach tej komisji, a także ponoszą wydatki związane z ich funkcjonowaniem, wypłatą wynagrodzeń i szkoleniem oraz zwrotem świadkom kosztów przejazdu. Wydatki te finansowane są z budżetu państwa $^{12}$.

Pracami komisji orzekającej kieruje jej przewodniczący powoływany przez Prezesa Rady Ministrów spośród kandydatów zgłoszonych przez prezesa izby, przy której funkcjonuje dana komisja. Członków komisji orzekających powołuje Prezes Rady Ministrów spośród kandydatów

12 Art. 70 ust. 1 u.o.n.d.f.p. i art. 17 ust. 1 pkt 1 ustawy z dnia 7 października 1992 r. o regionalnych izbach obrachunkowych (tekst jedn. Dz.U. 2012, poz.1113 ze zm.). 
zgłoszonych przez przewodniczących komisji. Regionalna Komisja Orzekająca w Sprawach o Naruszenie Dyscypliny Finansów Publicznych przy Regionalnej Izbie Obrachunkowej w Bydgoszczy poza Przewodniczącym pracuje w składzie sześciu Członków, z których jeden pełni funkcję Zastępcy Przewodniczącego.

Osoby dysponujące środkami publicznymi, które naruszają ustalony ład finansów publicznych, narażają się na restrykcje ze strony komisji orzekających. Ważne jest jednak - obok funkcji restrykcyjnej - pełnienie przez komisje także funkcji profilaktycznych w zakresie utrzymania porządku i ładu finansów publicznych. Regionalna Komisja Orzekająca przy Regionalnej Izbie Obrachunkowej w Bydgoszczy w swej działalności funkcję tę stosuje.

\section{Bibliografia:}

Babczuk A., Robaczyński W., Talik A., Dyscyplina finansów publicznych. Podstawy i zakres odpowiedzialności, C.H. Beck, Warszawa 2015.

Bojkowski T., Przybylska J., Dyscyplina finansów publicznych - zasady odpowiedzialności, problemy orzecznicze i aspekty praktyczne, CeDeWu, Warszawa 2012.

Lipiec-Warzecha L., Odpowiedzialność za naruszenie dyscypliny finansów publicznych. Komentarz, Wolters Kluwer, Warszawa 2012.

Motowilczuk I., Dyscyplina finansów publicznych po zmianach, INFOR, Warszawa 2012. 